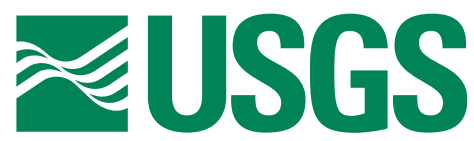

science for a changing world

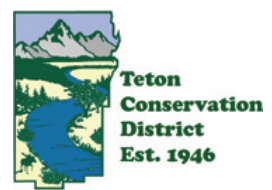

In Cooperation with Teton Conservation District

\title{
Seepage Investigation on Selected Reaches of Fish Creek, Teton County, Wyoming, 2004
}

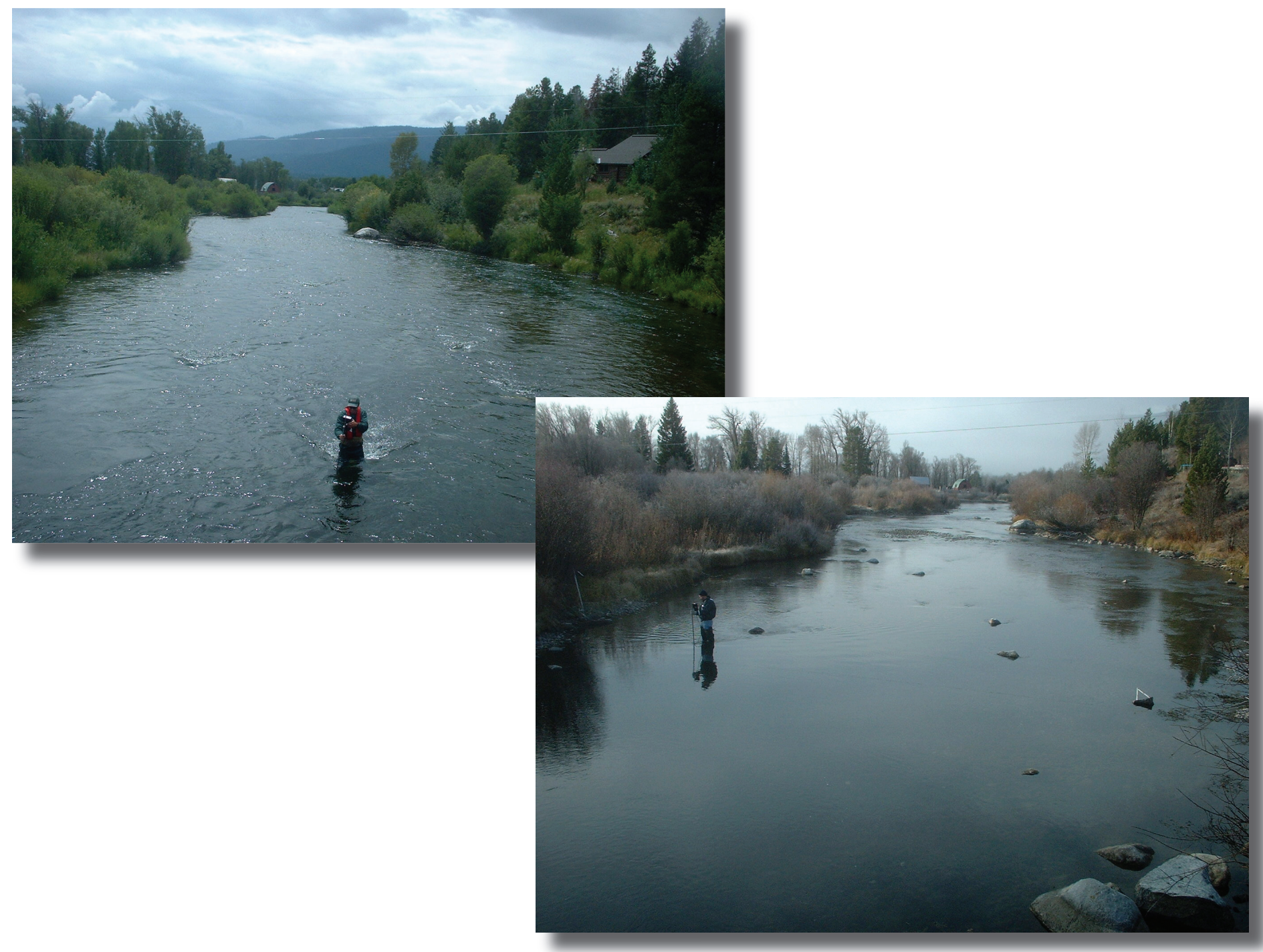

Scientific Investigations Report 2005-5133 
On the cover: Site R3D/R4U in August (left photograph) and November (right photograph), 2004. 


\section{Seepage Investigation on Selected Reaches of Fish Creek, Teton County, Wyoming, 2004}

By Jerrod D. Wheeler and Cheryl A. Eddy-Miller

In cooperation with Teton Conservation District

Scientific Investigations Report 2005-5133 


\section{U.S. Department of the Interior \\ Gale A. Norton, Secretary}

\section{U.S. Geological Survey \\ P. Patrick Leahy, Acting Director}

U.S. Geological Survey, Reston, Virginia: 2005

For sale by U.S. Geological Survey, Information Services
Box 25286, Denver Federal Center
Denver, CO 80225
For more information about the USGS and its products:
Telephone: 1-888-ASK-USGS
World Wide Web: http://www.usgs.gov/

Any use of trade, product, or firm names in this publication is for descriptive purposes only and does not imply endorsement by the U.S. Government.

Although this report is in the public domain, permission must be secured from the individual copyright owners to reproduce any copyrighted materials contained within this report. 


\section{Contents}

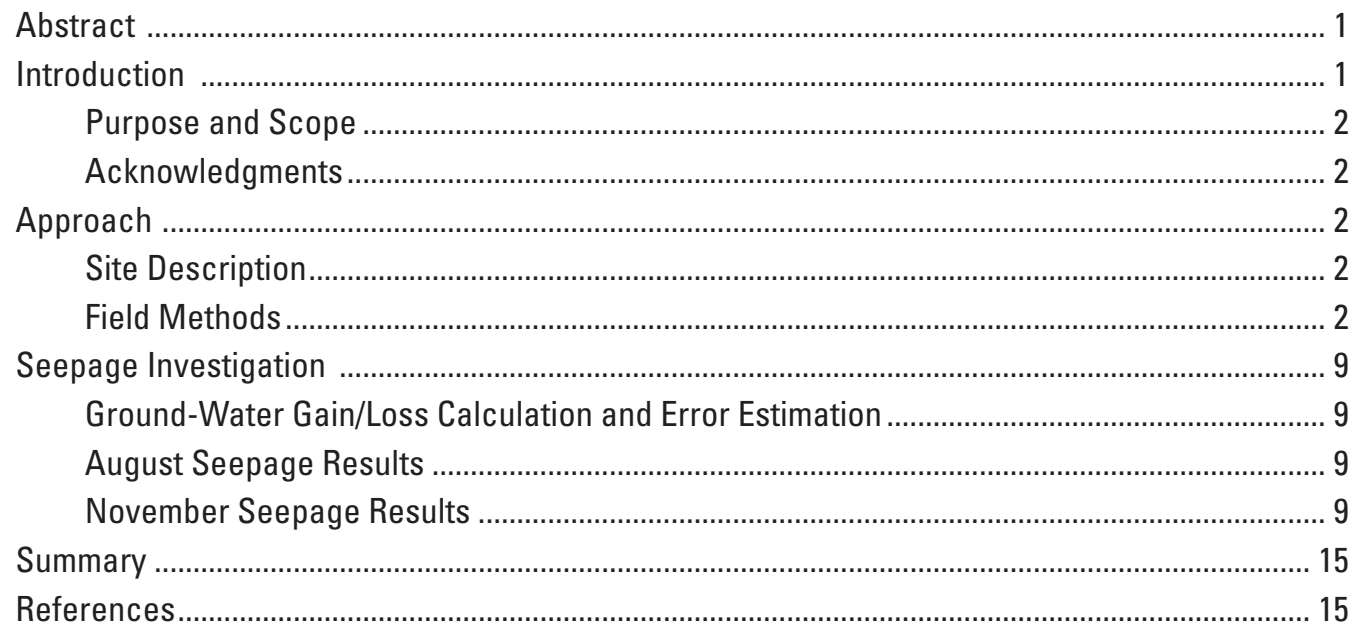

\section{Figures}

1. Map showing general location of Fish Creek, Wyoming ................................................. 3

2. Graph showing mean daily discharge during 2004 at Fish Creek at Wilson gaging

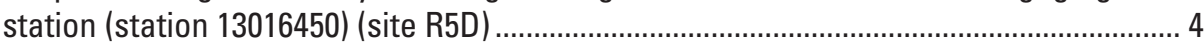

3a. Map showing Fish Creek seepage investigation study area, reaches, and site

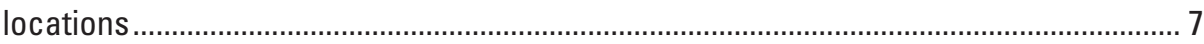

3b. Schematic of Reach 1 measurement sites for Fish Creek seepage investigation ........... 8

\section{Tables}

1. Fish Creek seepage measurement site descriptions and locations. .............................. 5

2. Discharge measurements on selected reaches of Fish Creek, Teton County, Wyoming, August 17-19, 2004

3. Summary of discharge measurements, selected reaches of Fish Creek, Teton County, Wyoming, August 17-19, 2004.

4. Discharge measurements on selected reaches of Fish Creek, Teton County, Wyoming, November 3-4, 2004

5. Summary of discharge measurements, selected reaches of Fish Creek, Teton County, Wyoming, November 3-4, 2004 


\section{Conversion Factors and Datums}

\begin{tabular}{lcl}
\hline Multiply & By & To obtain \\
\hline & Length & \\
foot $(\mathrm{ft})$ & 0.3048 & meter $(\mathrm{m})$ \\
mile $(\mathrm{mi})$ & 1.609 & kilometer $(\mathrm{km})$ \\
\hline & Area & \\
square mile $\left(\mathrm{mi}^{2}\right)$ & 2.590 & square kilometer $\left(\mathrm{km}^{2}\right)$ \\
\hline & Volume & \\
cubic foot $\left(\mathrm{ft}^{3}\right)$ & 0.02832 & cubic meter $\left(\mathrm{m}^{3}\right)$ \\
\hline & Flow rate & \\
cubic foot per second $\left(\mathrm{ft}^{3} / \mathrm{s}\right)$ & 0.02832 & cubic meter per second $\left(\mathrm{m}^{3} / \mathrm{s}\right)$ \\
\hline
\end{tabular}

Vertical coordinate information is referenced to the National Geodetic Vertical Datum of 1929 (NGVD 29).

Horizontal coordinate information is referenced to the North American Datum of 1983 (NAD 83).

Elevation, as used in this report, refers to distance above the vertical datum. 


\title{
Seepage Investigation on Selected Reaches of Fish Creek, Teton County, Wyoming, 2004
}

\author{
By Jerrod D. Wheeler and Cheryl A. Eddy-Miller
}

\section{Abstract}

A seepage investigation was conducted on Fish Creek, a tributary to the Snake River in Teton County in western Wyoming, near Wilson. Mainstem, return flow, tributary, spring, and diversion sites were selected and measured on six reaches along Fish Creek. Flow was measured under two flow regimes, high flow in August 2004 and base flow in November 2004.

During August 17-19, 2004, 20 sites had quantifiable discharge with median values ranging from 0.93 to $384 \mathrm{ft}^{3} / \mathrm{s}$ for the 14 mainstem sites on Fish Creek, and from 0.35 to $12.2 \mathrm{ft}^{3} / \mathrm{s}$ for the 5 return, spring, and tributary sites (inflows). The discharge was $2.23 \mathrm{ft}^{3} / \mathrm{s}$ for the single diversion site (outflow). Estimated gains or losses from ground water were calculated for all reaches using the median discharge values and the estimated measurement errors. Reach 1 had a calculated gain in discharge from ground water $\left(23.8 \pm 3.3 \mathrm{ft}^{3} / \mathrm{s}\right)$. Reaches 2-6 had no calculated gains in flow, greater than the estimated error, that could be attributed to ground water.

A second set of measurements were made under baseflow conditions during November 3-4, 2004. Twelve of the 20 sites visited in August 2004 were flowing and were measured. All of the Reach 1 sites near Teton Village were dry. Median discharge values ranged from 10.3 to $70.0 \mathrm{ft}^{3} / \mathrm{s}$ on the nine Fish Creek mainstem sites, and from 2.32 to $3.71 \mathrm{ft}^{3} / \mathrm{s}$ on the three return, spring, and tributary sites (inflows). Reaches 2, 3 and 6 had a gain from ground water. Reaches 4 and 5 had no calculated gains in flow, greater than the estimated error, that could be attributed to ground water.

\section{Introduction}

Fish Creek, a tributary to the Snake River, is about 15-river miles long, and is located in Teton County in western Wyoming near the town of Wilson (fig. 1). The drainage is located along the southwestern margin of a structural basin known as Jackson Hole, which is bounded by several uplifted ranges including the Teton, Snake River, and Gros Ventre Ranges (fig. 1), and the Wyoming, Hoback, and Washakie Ranges (not shown on fig. 1). The Teton Range is a northsouth trending upthrown fault-block, and Fish Creek flows to the southwest roughly parallel to the southern extent of the Teton fault to the west and the Snake River to the east. The surficial geology along Fish Creek between the Teton fault and the Snake River consists of Quaternary unconsolidated clay, silt, sand, gravel, cobble, and boulders. These deposits primarily include alluvium, colluvium, glacial till, and outwash deposits as a result of fluvial deposition and Pleistocene-age glaciations in the valley (Nolan and Miller, 1995).

Fish Creek's drainage area includes part of the southern extent of the Teton Range and the southwestern part of the Snake River valley, and is $71 \mathrm{mi}^{2}$ at the U.S. Geological Survey gaging station, Fish Creek at Wilson, Wyoming (station 13016450) (Swanson and others, 2002). Discharge in Fish Creek is intermittent in the upper reaches and perennial by the time the flow reaches Wilson, Wyoming. In a typical year, the mean daily discharge in Fish Creek increases over its reach from about 4 cubic feet per second $\left(\mathrm{ft}^{3} / \mathrm{s}\right)$ near Teton Village to more than $500 \mathrm{ft}^{3} / \mathrm{s}$ near Wilson during high flow in early summer, and from no flow near Teton Village to about $40 \mathrm{ft}^{3} / \mathrm{s}$ near Wilson during base-flow conditions (Swanson and others, 2002; 2003). Figure 2 shows the mean daily discharge in Fish Creek at Wilson, Wyoming (gaging station 13016450) during 2004. The changes in flow can be attributed to both ground water and surface water. The ground-water table near Fish Creek can rise due to recharge from local flood irrigation, injection of tertiary treated sewage, or the loss of water from Lake Creek (a diversion from the Snake River) (Nelson Engineering, 1992). Surface-water inputs were springs, irrigation return flows, and tributary streams, and outputs were diversions.

The U.S. Geological Survey (USGS) in cooperation with the Teton Conservation District conducted a seepage investigation of selected reaches of Fish Creek during 2004. The objective of the investigation was to estimate the magnitude of gains and losses in streamflow over six independent reaches of Fish Creek during two different flow regimes. In August, the stream discharge is high and highly affected by irrigation infiltration and return flows. In November, the stream is at base-flow conditions, when the primary source of water gain to the stream is from ground water (fig. 2). Measurements were made prior to the low-flow period, because snow depths after mid-November would preclude finding the locations of channel inflows and outflows. 
This investigation was conducted to better understand the ground-water/surface-water interaction between Fish Creek and the local ground water. The scope of the investigation was limited to measuring discharge at the upstream and downstream end of a selected reach, measuring all identifiable surface-water inputs and diversions from the stream reach, then calculating the change in flow. The change in flow can be attributed to the sum of the ground-water input/output to the stream and undetermined surface-water inputs.

\section{Purpose and Scope}

The purpose of this report is to present the results of the seepage investigation on Fish Creek during August 17-19 and November 3-4, 2004. The discharge measurements at 20 sites, which include 14 mainstem sites, 2 return flow sites, 1 spring, 2 tributary sites, and 1 diversion site, are presented. The calculated streamflow gains and losses attributed to ground water along six reaches of Fish Creek also are presented.

\section{Acknowledgments}

The authors gratefully acknowledge the generous assistance of area landowners near Fish Creek who provided access to their property for this study. The authors also acknowledge assistance from Brian Remlinger, Teton Conservation District, with site selection and from Kirk Miller and Ty Blacklock, U.S. Geological Survey, with discharge measurements.

\section{Approach}

Six reaches along Fish Creek were selected for the investigation (figs. $3 \mathrm{a}$ and $3 \mathrm{~b}$ ). The reaches were selected to be a distance long enough to potentially determine change, but short enough to provide interpretable and useful data. The reaches were selected to be approximately the same length. All visible inputs to and outputs from the creek in each reach were georeferenced using a Global Positioning System (GPS) and documented. The most upstream site (R1U) was located approximately where Fish Creek leaves the Teton Range and enters the Snake River valley. The most downstream site (R6D) was located approximately 1 mile south of Wilson, Wyoming. No reaches were selected downstream from R6D, as Fish Creek enters a very marshy area with many braided inflows to and outflows from the creek, and determinations of discharge would not have been feasible.

Two sets of discharge measurements were made on the selected reaches on Fish Creek. The first set was measured during August 17-19, 2004 during high-flow conditions. The second set was measured on November 3-4, 2004, during base-flow conditions.

\section{Site Description}

A total of 20 sites (14 mainstem, 2 return flow, 1 spring, 2 tributary, and 1 diversion) were selected in the 6 reaches evaluated during the investigation (figs. $3 a$ and $3 b$; table 1). Two sites (R3D/R4U and R4D/R5U) served as both the downstream point for one reach and the upstream point for the next reach. Site R5D is located at the Fish Creek at Wilson, Wyoming gaging station (13016450).

The entire section of Fish Creek in Reach 1 was recently rechannelized (December 2003-January 2004 (Brian Remlinger, personal commun., 2004)). The creek was changed from a straight channel through a meadow to an engineered, meandering stream. The creek in and downstream from Reach 2 has had minimal channel adjustments.

Discharge from springs enter the creek between Reach 1 and Reach 2. That section of Fish Creek was not included in the study, however, because a large amount of overland flow into the creek from irrigation return flows occurred in August, which could not be quantified.

The elevation of Fish Creek decreases from about 6,280 feet above the National Geodetic Vertical Datum of 1929 (NGVD 29) at the uppermost part of the study (site R1U) to about 6,120 feet above the NGVD 29 at the lower part of the study (site R6D). The length of Fish Creek studied (from R1U to R6D) is about 10 miles.

\section{Field Methods}

All discharge measurements collected during this study were made using standard USGS discharge measurement protocols (Rantz and others, 1982; Nolan and Shields, 2000). Acoustic Doppler Velocity (ADV) meters were used exclusively due to their ability to provide high-resolution velocity data and their suitability in shallow stream environments. Fluctuations in stage were monitored at each measurement location either by using existing staff gages or by setting up temporary reference marks and measuring to the water surface. At all sites, stage did not substantially change during each set of discharge measurements at individual sites, with observed maximum fluctuations of $\pm 0.03 \mathrm{ft}$.

Cross-section locations were selected where possible to maximize favorable flow conditions (for example, uniform cross-section, perpendicular flow, non-turbulent flow) and minimize potential errors due to factors such as heavy aquatic plant growth, uneven streambeds, and irregular velocity profiles. Some cross-section locations were dictated by stream access, and as such, channel and flow conditions may not have been ideal.

Discharge was measured in upstream to downstream order during both flow regimes. At least two measurements, performed either concurrently or sequentially, were made at each mainstem site. If the difference between the two measurements was greater than 5 percent, an additional measurement was performed to improve precision. Single measure- 


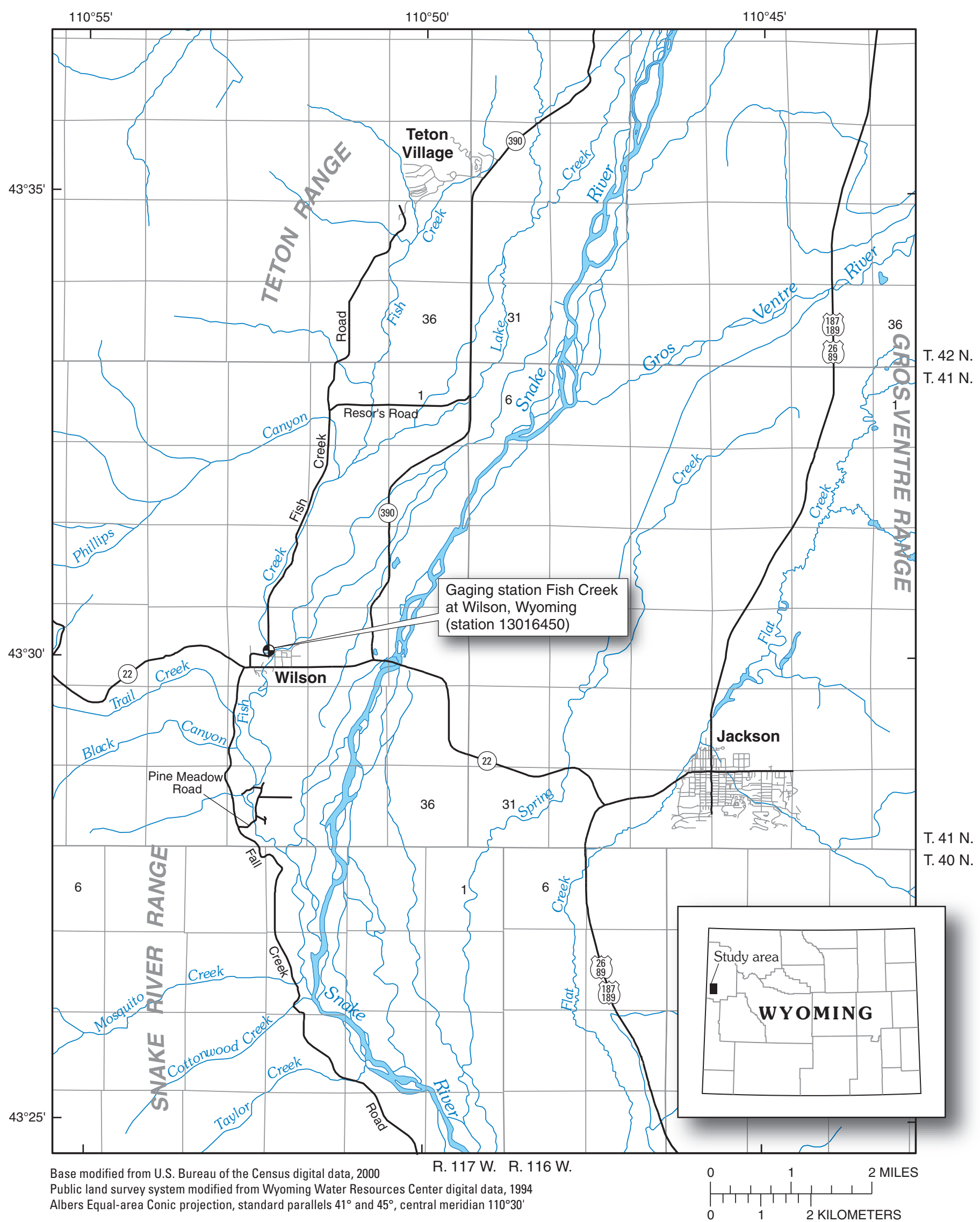

Figure 1. General location of Fish Creek, Wyoming. 


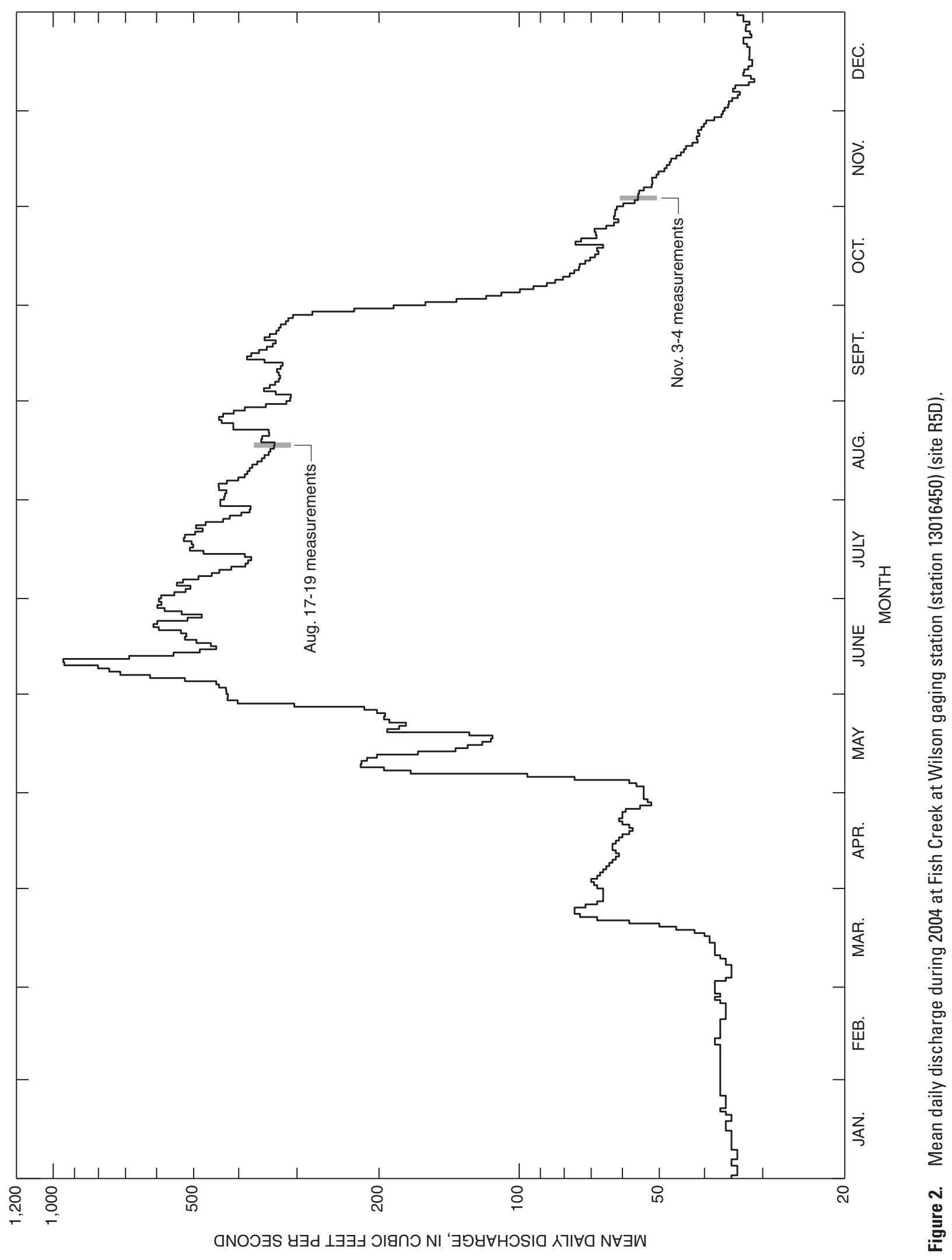


ments were made for very small channels, return flows, and springs. Exceptions were a single measurement made at R6U during August and two measurements at R1DrnA.

Notations were made in the field to indicate sites that were dry or where flow was less than $0.1 \mathrm{ft}^{3} / \mathrm{s}$. At sites where the flow was less than $0.1 \mathrm{ft}^{3} / \mathrm{s}$, the flow was reported as zero. For sites where flow was greater than $0.1 \mathrm{ft}^{3} / \mathrm{s}$, the discharge was rounded to three significant figures.

The hydrograph for the stream gaging station, Fish Creek at Wilson, Wyoming (13016450), was examined to ensure that any effect of rain falling on the Fish Creek watershed had dissipated prior to making discharge measurements. Measurements made on a specific reach were completed in 1 day to minimize any variations in flow rates that might occur overnight.

Consideration was given to the computed discharge at the Fish Creek gaging station at Wilson, Wyoming, located at site R5D, as an indicator of the general hydrologic conditions in the study area. Mean daily discharge at gaging station 13016450 ranged from 335 to $336 \mathrm{ft}^{3} / \mathrm{s}$ during August 17-19, 2004, and was $53 \mathrm{ft}^{3} / \mathrm{s}$ during November 3-4, 2004, demonstrating consistent flow conditions.

Table 1. Fish Creek seepage measurement site descriptions and locations.

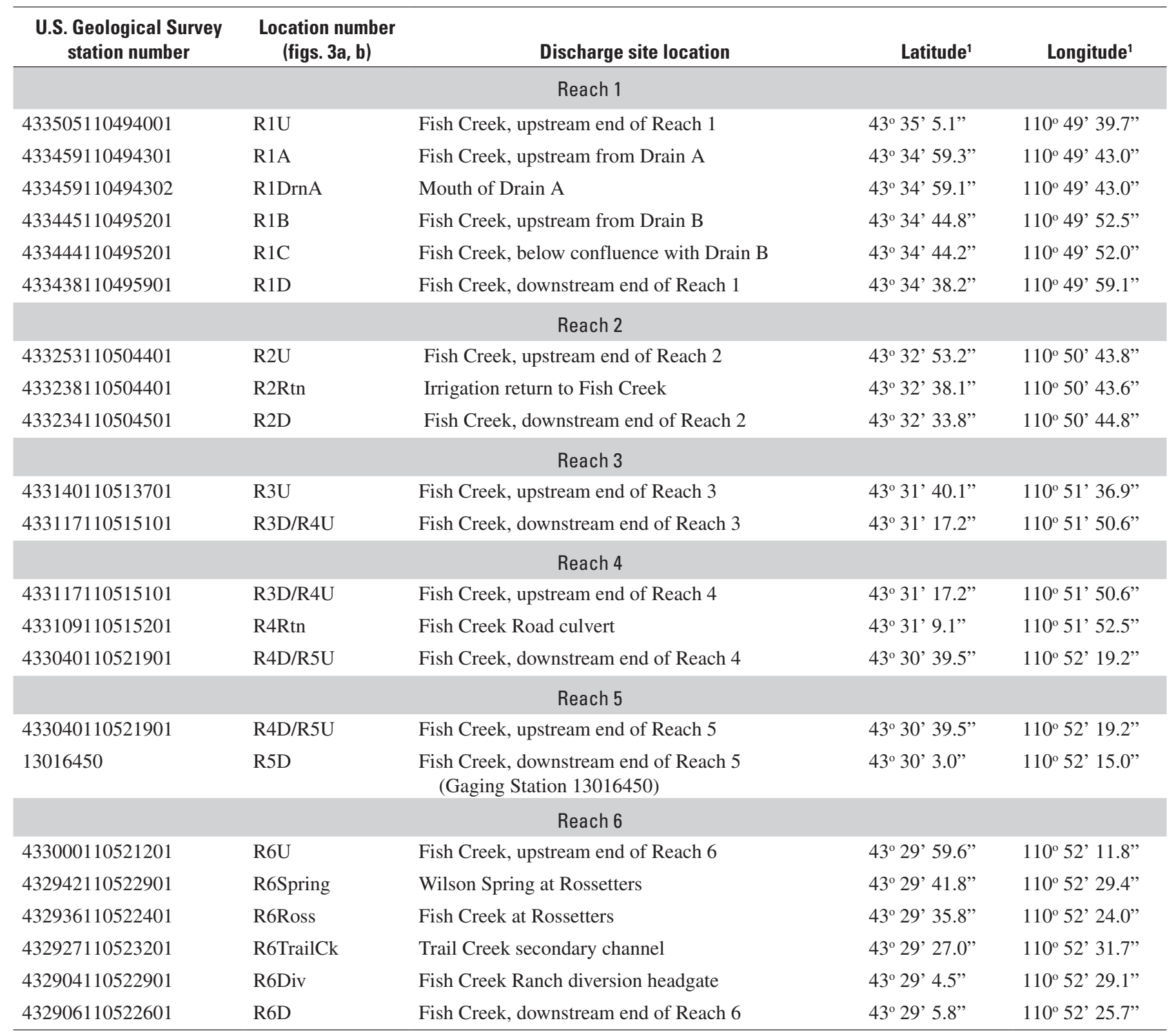

${ }^{1}$ All latitude and longitude measurements were obtained with a handheld Global Positioning System (GPS). 


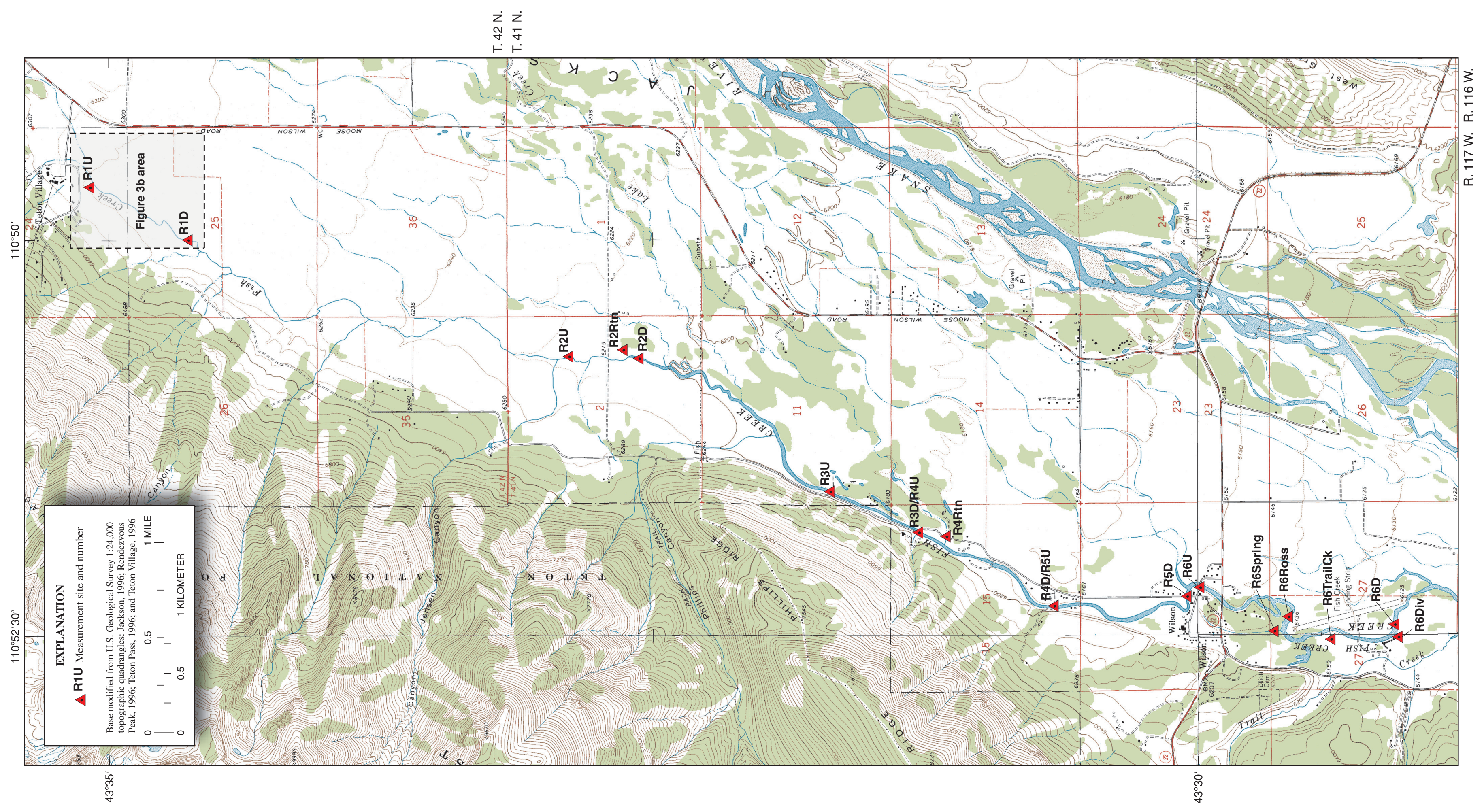




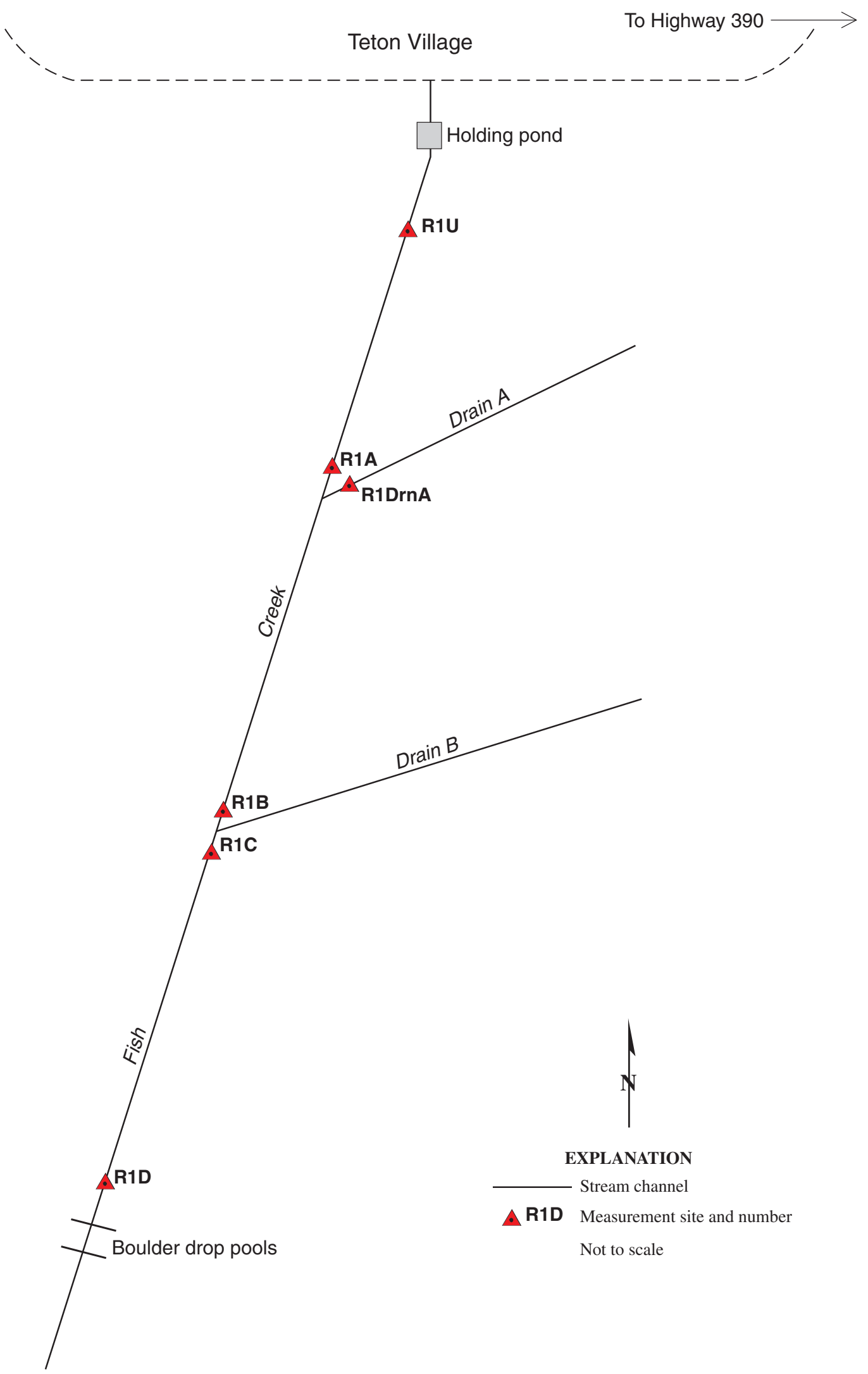

Figure 3b. Schematic of Reach 1 measurement sites for Fish Creek seepage investigation. 


\section{Seepage Investigation}

Ground-water gain/loss was calculated for each of the six reaches for both the August and November investigations. Error estimation was determined for all reaches.

\section{Ground-Water Gain/Loss Calculation and Error Estimation}

For all reaches with measurable flow, streamflow gains and losses attributed to ground water were calculated using the median discharge values for each site. The change in streamflow for each reach was calculated by subtracting the discharge at the most upstream site from the most downstream site. Streamflow gains and losses attributed to ground water within each reach were calculated by subtracting input flows (irrigation returns, tributaries, or springs), and by adding output flows attributed to diversions to the difference of the upstream and downstream discharge. For these calculations, the springs were considered a surface-water input to the creek. The original source of spring water is ground water; however, the effect of that spring on Fish Creek is that of a quantifiable surface-water input.

A level of uncertainty or measurement error is associated with each discharge measurement made during this investigation. This uncertainty, also know as measurement error, standard error, or indeterminate error, results from inherent inaccuracies associated with the equipment and techniques used during each individual discharge measurement. The source of these uncertainties in USGS discharge measurements have been analyzed and a rating system has been developed to estimate this measurement error of individual discharge measurements (Sauer and Meyer, 1992). This rating system was used in this investigation to estimate measurement error for each discharge measurement as follows: good (measured discharge within 5 percent of the actual discharge ( 5 percent used for calculations in this report)); fair (between 5 and 8 percent ( 8 percent used for calculations in this report)); and poor (measured discharge 8 percent greater or less than the actual discharge (10 percent used for calculations in this report)). The measurement error associated with a calculated streamflow gain/loss attributed to ground water is a function of the measurement errors from all of the discharge measurements used to calculate that loss or gain.

The calculated value of each ground-water gain/loss has an associated estimated measurement error. This estimated error(s) was calculated by using the following propagation of error formula:

$$
s=\sqrt{( \pm a)^{2}+( \pm b)^{2} \ldots+( \pm n)^{2}}
$$

where $s$ is the error propagated from all estimated individual errors and $a, b, \ldots, n$ are the estimated errors for the median discharge measurement at each site.
Estimated measurement accuracy ranged from approximately 3-5 percent error at sites with high discharge, typically at downstream reaches, to greater than 8 percent error at sites with very low discharge and/or considerable aquatic growth.

\section{August Seepage Results}

All 20 selected sites had appreciable flowing water during August 17-19, 2004, and discharge was measured on the mainstem, return flow, tributary, and diversion sites of Fish Creek (table 2). A summary of the measurements and calculated gains/losses from ground water are shown in table 3 . Median discharges ranged from 0.93 to $384 \mathrm{ft}^{3} / \mathrm{s}$ for the mainstem of Fish Creek, and from 0.35 to $12.2 \mathrm{ft}^{3} / \mathrm{s}$ for return, spring, and tributary sites (inflows). Discharge was $2.23 \mathrm{ft}^{3} / \mathrm{s}$ for the single diversion (outflow) measurement at the diversion structure located on the downstream end of Reach 6 . Reach 1 had a calculated gain of ground water $\left(23.8 \pm 3.3 \mathrm{ft}^{3} / \mathrm{s}\right)$ greater than the estimated measurement error (table 3 ). Calculated streamflow gains/losses attributed to ground water in Reaches 2-6 were smaller than the estimated measurement errors.

\section{November Seepage Results}

All of the study sites that were measured during August 17-19, 2004 were revisited during November 3-4, 2004 to make base-flow measurements (table 4); 12 sites had flowing water and were remeasured. All of the Reach 1 sites near Teton Village were dry. The return flow on Reach 2, site $\mathrm{R} 2 \mathrm{Rtn}$, was estimated as less than $0.10 \mathrm{ft}^{3} / \mathrm{s}$ and was reported as zero. In addition, the diversion structure on Reach 6 was no longer diverting water and site R6Div was dry. A summary of the measurements and calculated streamflow gains/losses attributed to ground water are shown in table 5. Median discharge at the nine mainstem sites ranged from 10.3 to $70.0 \mathrm{ft}^{3} / \mathrm{s}$, and from 2.32 to $3.71 \mathrm{ft}^{3} / \mathrm{s}$ on the three return, spring, and tributary sites (inflows). Reaches 2, 3, and 6 had calculated gains from ground water $\left(2.8 \pm 1.1 \mathrm{ft}^{3} / \mathrm{s}\right.$ for Reach 2 ; $7.2 \pm 5.6 \mathrm{ft}^{3} / \mathrm{s}$ for Reach 3 ; and $8.4 \pm 7.5 \mathrm{ft}^{3} / \mathrm{s}$ for Reach 6 ) that were greater than the estimated measurement errors (table 5). Calculated streamflow gains/losses attributed to ground water in Reaches 4 and 5 were smaller than the estimated measurement errors. 
Table 2. Discharge measurements on selected reaches of Fish Creek, Teton County, Wyoming, August 17-19, 2004.

[Discharge Measurement Quality: $(\mathrm{G})$, good (less than 5 percent error), (F), fair (5-8 percent error), (P), poor (greater than 8 percent error); $\mathrm{ft}^{3} / \mathrm{s}$, cubic feet per second; ft/s, feet per second; ft, feet; --, not applicable]

\begin{tabular}{|c|c|c|c|c|c|c|}
\hline $\begin{array}{l}\text { Location } \\
\text { number }\end{array}$ & $\begin{array}{c}\text { Discharge } \\
\text { measurements on } \\
\text { mainstem }\left(\mathrm{ft}^{3} / \mathrm{s}\right)\end{array}$ & $\begin{array}{c}\text { Discharge } \\
\text { measurements } \\
\text { on return/spring/ } \\
\text { tributary }(+) \text { or } \\
\text { diversion (-) } \\
\left(\mathrm{ft}^{3} / \mathrm{s}\right)\end{array}$ & $\begin{array}{l}\text { Mean } \\
\text { velocity } \\
\text { (ft/s) }\end{array}$ & $\begin{array}{c}\text { Mean } \\
\text { depth } \\
(f t)\end{array}$ & $\begin{array}{l}\text { Mean } \\
\text { channel } \\
\text { width' }^{1} \\
\text { (ft) }\end{array}$ & Remarks \\
\hline \multicolumn{7}{|c|}{ Reach 1} \\
\hline $\mathrm{R} 1 \mathrm{U}$ & $0.83,0.93,0.96(\mathrm{P})$ & -- & 0.61 & 0.23 & 6.40 & $\begin{array}{l}\text { Very shallow with slow velocities. Minor } \\
\text { aquatic growth. }\end{array}$ \\
\hline $\mathrm{R} 1 \mathrm{~A}$ & $3.27,3.39(\mathrm{P})$ & -- & .80 & .72 & 5.90 & Very shallow, irregular bed. \\
\hline R1DrnA & -- & (+) $3.81,3.82(\mathrm{P})$ & 1.17 & .58 & 5.60 & Very shallow, turbulent flow. \\
\hline R1B & $19.7,20.0(\mathrm{~F})$ & -- & 1.22 & 1.38 & 11.5 & Uniform bed. Even, steady flow. \\
\hline $\mathrm{R} 1 \mathrm{C}$ & $32.0,32.1(\mathrm{G})$ & -- & 2.74 & 1.06 & 11.0 & Uniform bed. Even, steady flow on riffle. \\
\hline R1D & $40.7,40.9(\mathrm{G})$ & -- & 1.70 & 1.46 & 16.4 & Good cross-section. Even, steady flow. \\
\hline R2Rtn & -- & $(+) 0.35(\mathrm{P})$ & .41 & .33 & 2.60 & $\begin{array}{l}\text { Shallow and narrow, only } 8 \text { subsections } \\
\text { measured. Heavy aquatic growth. }\end{array}$ \\
\hline R2D & $118,120(\mathrm{G})$ & -- & 3.32 & 1.22 & 29.5 & $\begin{array}{l}\text { Fairly even cross-section. Smooth, steady } \\
\text { flow. }\end{array}$ \\
\hline \multicolumn{7}{|c|}{ Reach 3} \\
\hline R3U & 297, $300(\mathrm{G})$ & -- & 2.56 & 1.70 & 69.0 & $\begin{array}{l}\text { Good cross-section. Left bank vertical. Even } \\
\text { flow, unsteady velocity. }\end{array}$ \\
\hline R3D/R4U & 293, $299(\mathrm{~F})$ & -- & 2.62 & 1.82 & 62.2 & $\begin{array}{l}\text { Fair cross-section. Moderate aquatic growth. } \\
\text { Uneven flow. }\end{array}$ \\
\hline \multicolumn{7}{|c|}{ Reach 4} \\
\hline R4D/R5U & $313,318(\mathrm{~F})$ & -- & 2.42 & 2.18 & 60.0 & $\begin{array}{l}\text { Moderate to heavy aquatic growth in chan- } \\
\text { nel. }\end{array}$ \\
\hline R5D & $333,325(\mathrm{G})$ & -- & 3.88 & 1.44 & 59.0 & $\begin{array}{l}\text { Uneven, turbulent flow on riffle } 100 \mathrm{ft} \text { up- } \\
\text { stream from gaging station. }\end{array}$ \\
\hline \multicolumn{7}{|c|}{ Reach 6} \\
\hline R6U & $376(\mathrm{G})$ & -- & 3.71 & 1.58 & 64.0 & $\begin{array}{l}\text { Good cross-section. Even, smooth flow with } \\
\text { swift, steady velocities. }\end{array}$ \\
\hline R6Spring & -- & $(+) 6.10(\mathrm{P})$ & 1.58 & 0.58 & 6.70 & $\begin{array}{l}\text { Measured outflow from two culvert pipes } \\
150-200 \mathrm{ft} \text { upstream from spring/stream } \\
\text { confluence. }\end{array}$ \\
\hline R6Ross & $354,387(\mathrm{~F})$ & -- & 2.80 & 1.38 & 97.0 & $\begin{array}{l}\text { Uniform streambed. Moderate to heavy } \\
\text { aquatic growth near bottom. }\end{array}$ \\
\hline R6TrailCk & -- & $(+) 0.50(\mathrm{P})$ & .30 & .48 & 3.50 & $\begin{array}{l}\text { Uneven, large cobble streambed. Turbulent } \\
\text { and uneven flow. }\end{array}$ \\
\hline R6Div & -- & (-) $2.23(\mathrm{P})$ & .60 & 1.24 & 3.00 & $\begin{array}{l}\text { Small, narrow ditch. Few subsections mea- } \\
\text { sured. }\end{array}$ \\
\hline R6D & $376,391(\mathrm{G})$ & -- & 2.98 & 1.54 & 84.0 & Uniform, even flow. Steady velocities. \\
\hline
\end{tabular}

${ }^{1}$ Mean velocity, depth, and channel width for each set of measurements at a location were calculated by averaging the mean velocities, depths, and channel widths of each individual discharge measurement. 
Table 3. Summary of discharge measurements, selected reaches of Fish Creek, Teton County, Wyoming, August 17-19, 2004.

Discharge Measurement Quality: (G), good (less than 5 percent error, with 5 percent error used in calculation), (F), fair (5-8 percent error, with 8 percent error used in calculation), (P), poor (greater than 8 percent error, with 10 percent error used in calculation); $\mathrm{ft}^{3} / \mathrm{s}$, cubic feet per second; --, not applicable or no remarks]

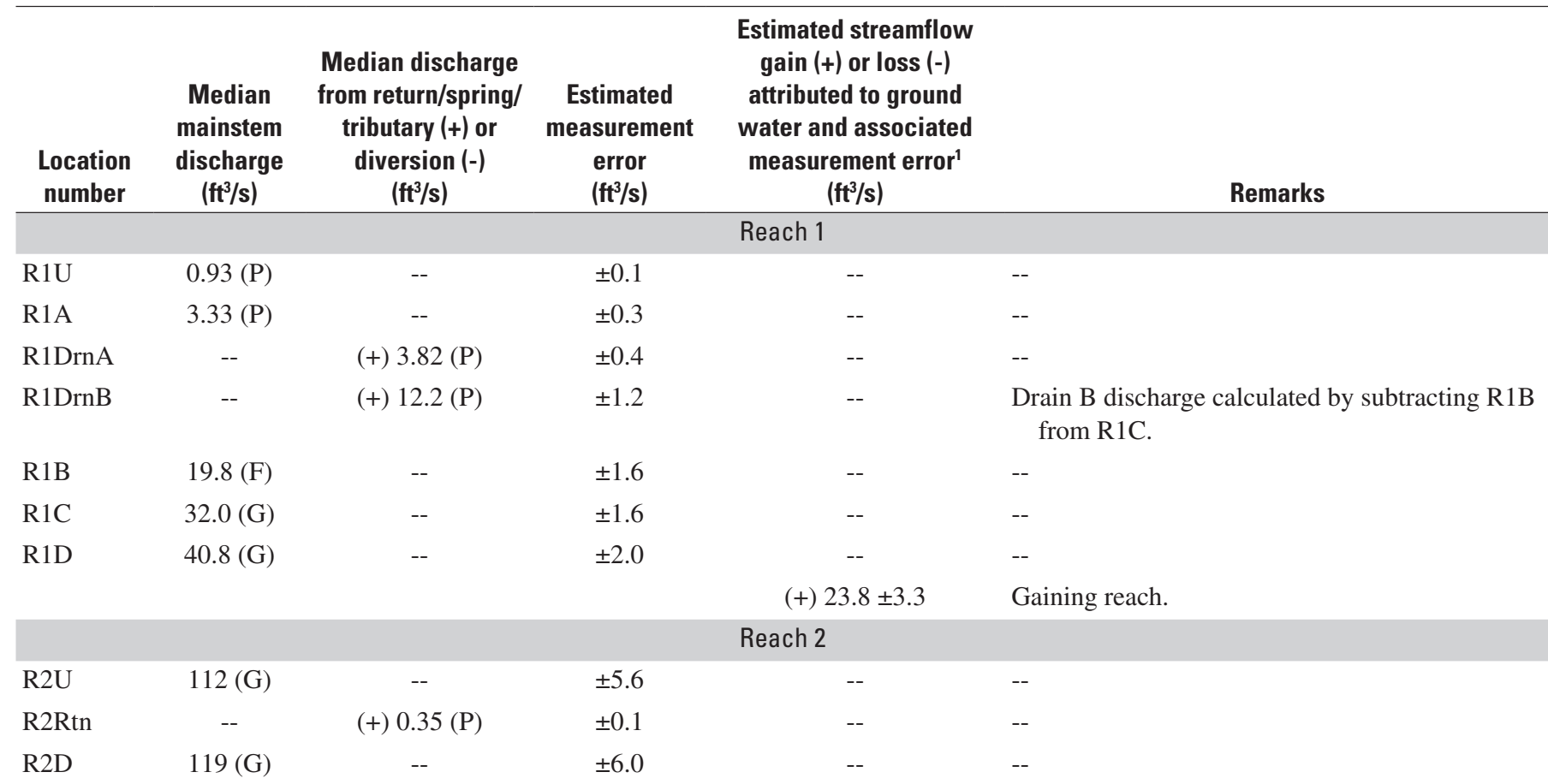

(+) $6.65 \pm 8.2 \quad$ Difference in measured discharge is less than the associated measurement error.

\begin{tabular}{llllll} 
& \multicolumn{3}{c}{ Reach 3 } \\
R3U & $298(\mathrm{G})$ & -- & \pm 14.9 & - \\
R3D/R4U & $296(\mathrm{~F})$ & -- & \pm 23.7 & --
\end{tabular}

(-) $2.0 \pm 28.0 \quad$ Difference in measured discharge is less than the associated measurement error.

\begin{tabular}{lccccc} 
& \multicolumn{3}{c}{ Reach 4} \\
R3D/R4U & $296(\mathrm{~F})$ & -- & \pm 23.7 & -- & -- \\
R4Rtn & -- & $(+) 6.31(\mathrm{~F})$ & \pm 0.5 & -- & -- \\
R4D/R5U & $316(\mathrm{~F})$ & -- & \pm 25.3 & --
\end{tabular}

(+) $13.7 \pm 34.7 \quad$ Difference in measured discharge is less than the associated measurement error.

\begin{tabular}{llllll} 
& \multicolumn{3}{c}{ Reach 5 } \\
R4D/R5U & $316(\mathrm{~F})$ & -- & \pm 25.3 & -- & - \\
R5D & $329(\mathrm{G})$ & -- & \pm 16.4 & --
\end{tabular}

(+) $13.0 \pm 30.2 \quad$ Difference in measured discharge is less than the associated measurement error. 


\section{Seepage Investigation on Selected Reaches of Fish Creek, Teton County, Wyoming, 2004}

Table 3. Summary of discharge measurements, selected reaches of Fish Creek, Teton County, Wyoming, August 17-19, 2004. Continued

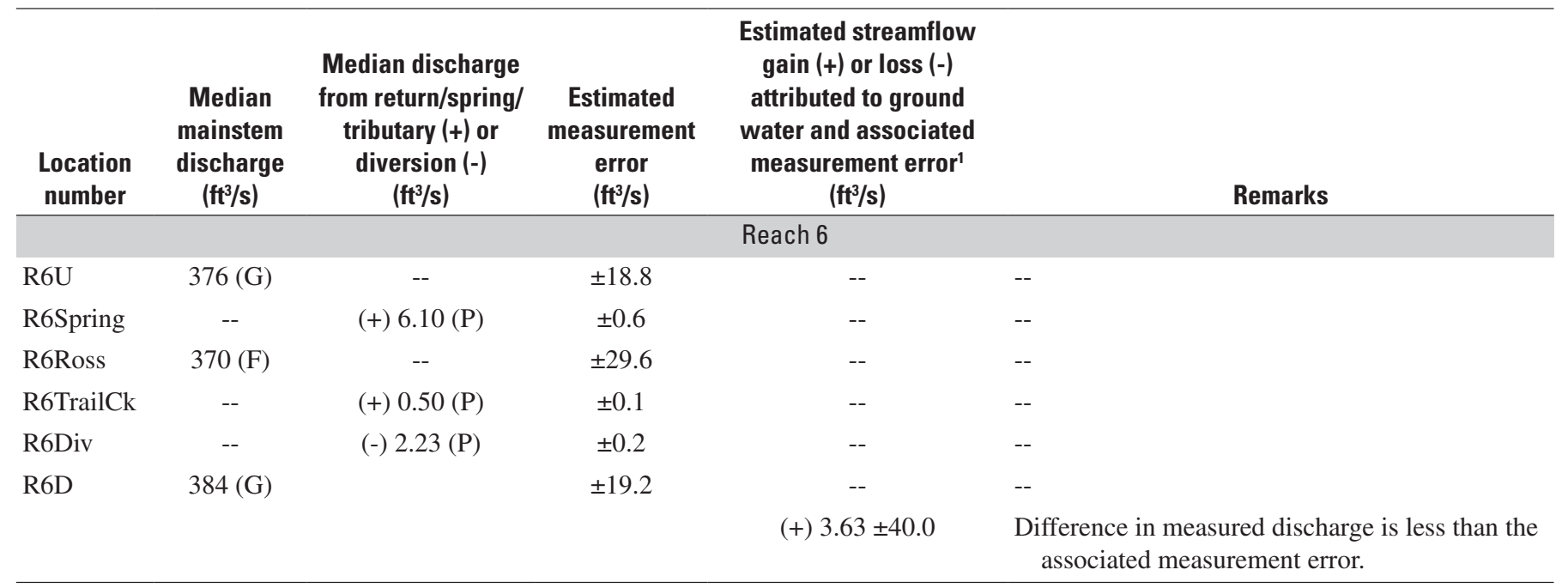

${ }^{1}$ Measurement error for the streamflow gain or loss attributed to ground water was calculated using the following propagation of error formula:

$$
s=\sqrt{( \pm a)^{2}+( \pm b)^{2} \ldots+( \pm n)^{2}}
$$

Where $s$ is the error propagated from all estimated individual errors and $a, b, \ldots, n$ are the estimated errors for the median discharge measurement at each site. 
Table 4. Discharge measurements on selected reaches of Fish Creek, Teton County, Wyoming, November 3-4, 2004.

[Discharge Measurement Quality: (G), good (less than 5 percent error), (F), fair (5-8 percent error), (P), poor (greater than 8 percent error); $\mathrm{ft}^{3} / \mathrm{s}$, cubic feet per second; ft/s, feet per second; ft, feet; --, not applicable]

\begin{tabular}{|c|c|c|c|c|c|c|}
\hline $\begin{array}{l}\text { Location } \\
\text { number }\end{array}$ & $\begin{array}{c}\text { Discharge } \\
\text { measurements } \\
\text { on mainstem } \\
\left(\mathrm{ft}^{3} / \mathrm{s}\right)\end{array}$ & $\begin{array}{c}\text { Discharge } \\
\text { measurements } \\
\text { on return/spring/ } \\
\text { tributary }(+) \text { or } \\
\text { diversion }(-) \\
\left(\mathrm{ft}^{3} / \mathrm{s}\right)\end{array}$ & $\begin{array}{l}\text { Mean } \\
\text { velocity } \\
\text { (ft/s) }\end{array}$ & $\begin{array}{c}\text { Mean } \\
\text { depth' } \\
\text { (ft) }\end{array}$ & $\begin{array}{l}\text { Mean } \\
\text { channel } \\
\text { width' } \\
\text { (ft) }\end{array}$ & Remarks \\
\hline \multicolumn{7}{|c|}{ Reach 1} \\
\hline R1DrnA & -- & Dry & -- & -- & -- & -- \\
\hline R1B & Dry & -- & -- & -- & -- & -- \\
\hline $\mathrm{R} 1 \mathrm{C}$ & Dry & -- & -- & -- & -- & -- \\
\hline R1D & Dry & -- & -- & -- & -- & -- \\
\hline \multicolumn{7}{|c|}{ Reach 2} \\
\hline $\mathrm{R} 2 \mathrm{D}$ & $13.2,13.0(\mathrm{G})$ & -- & 0.94 & 0.62 & 23.0 & $\begin{array}{l}\text { Even cross-section above riffle. Even and steady } \\
\text { flow. }\end{array}$ \\
\hline \multicolumn{7}{|c|}{ Reach 3} \\
\hline $\mathrm{R} 3 \mathrm{U}$ & $\begin{array}{c}47.2,50.6,44.5 \\
42.6(\mathrm{~F})\end{array}$ & -- & 1.00 & 0.72 & 64.0 & $\begin{array}{l}\text { Uneven cross-section, shallow right side. Most of } \\
\text { flow at left-center. }\end{array}$ \\
\hline $\mathrm{R} 3 \mathrm{D} / \mathrm{R} 4 \mathrm{U}$ & $\begin{array}{c}54.0,50.4,52.6 \\
53.4(\mathrm{~F})\end{array}$ & -- & 0.85 & 1.04 & 60.0 & $\begin{array}{l}\text { Moderate aquatic growth, right side shallow. } \\
\text { Uneven flow. }\end{array}$ \\
\hline \multicolumn{7}{|c|}{ Reach 4} \\
\hline $\mathrm{R} 3 \mathrm{D} / \mathrm{R} 4 \mathrm{U}$ & $54.1,52.1(\mathrm{~F})$ & -- & 0.90 & 1.05 & 56.0 & $\begin{array}{l}\text { Moderate aquatic growth, right side shallow. } \\
\text { Uneven flow. }\end{array}$ \\
\hline R5D & $56.1,53.9(\mathrm{~F})$ & -- & 2.06 & 0.66 & 40.0 & $\begin{array}{l}\text { Aquatic growth present but receding. Meas. } 100 \\
\mathrm{ft} \text { upstream of gaging station. }\end{array}$ \\
\hline \multicolumn{7}{|c|}{ Reach 6} \\
\hline R6U & $\begin{array}{c}55.7,49.8,52.8 \\
61.9(\mathrm{~F})\end{array}$ & -- & 1.75 & 0.54 & 58.0 & $\begin{array}{l}\text { Multiple flow angles in cross-section. Moderate } \\
\text { aquatic growth. }\end{array}$ \\
\hline R6Spring & -- & $(+) 3.71(\mathrm{P})$ & 1.72 & 0.34 & 6.40 & $\begin{array}{l}\text { Measured outflow from two culvert pipes 150- } \\
200 \mathrm{ft} \text { above spring/stream confluence. }\end{array}$ \\
\hline R6Ross & $53.0,49.9(\mathrm{G})$ & -- & 0.91 & 0.63 & 90.0 & $\begin{array}{l}\text { Even cross-section. Less aquatic growth than } \\
\text { August event. }\end{array}$ \\
\hline R6TrailCk & -- & $(+) 3.64(\mathrm{P})$ & 1.56 & 0.40 & 5.80 & $\begin{array}{l}\text { Uneven, large cobble streambed. Turbulent and } \\
\text { uneven flow. }\end{array}$ \\
\hline R6Div & -- & Dry & -- & -- & -- & -- \\
\hline R6D & $\begin{array}{c}71.5,64.5,68.4 \\
76.8(\mathrm{~F})\end{array}$ & -- & 1.15 & 0.71 & 86.0 & $\begin{array}{l}\text { Moderate to heavy near-bottom aquatic growth. } \\
\text { Flow uneven, mostly in left and right-center of } \\
\text { channel. }\end{array}$ \\
\hline
\end{tabular}

${ }^{1}$ Mean velocity, depth, and channel width for each set of measurements at a location were calculated by averaging the mean velocities, depths, and channel widths of each individual discharge measurement. 
Table 5. Summary of discharge measurements, selected reaches of Fish Creek, Teton County, Wyoming, November 3-4, 2004.

Discharge Measurement Quality: (G), good (less than 5 percent error, with 5 percent error used in calculation), (F), fair (5-8 percent error, with 8 percent error used in calculation), (P), poor (greater than 8 percent error, with 10 percent error used in calculation); $\mathrm{ft}^{3} / \mathrm{s}$, cubic feet per second; --, not applicable or no remarks; <, less than]

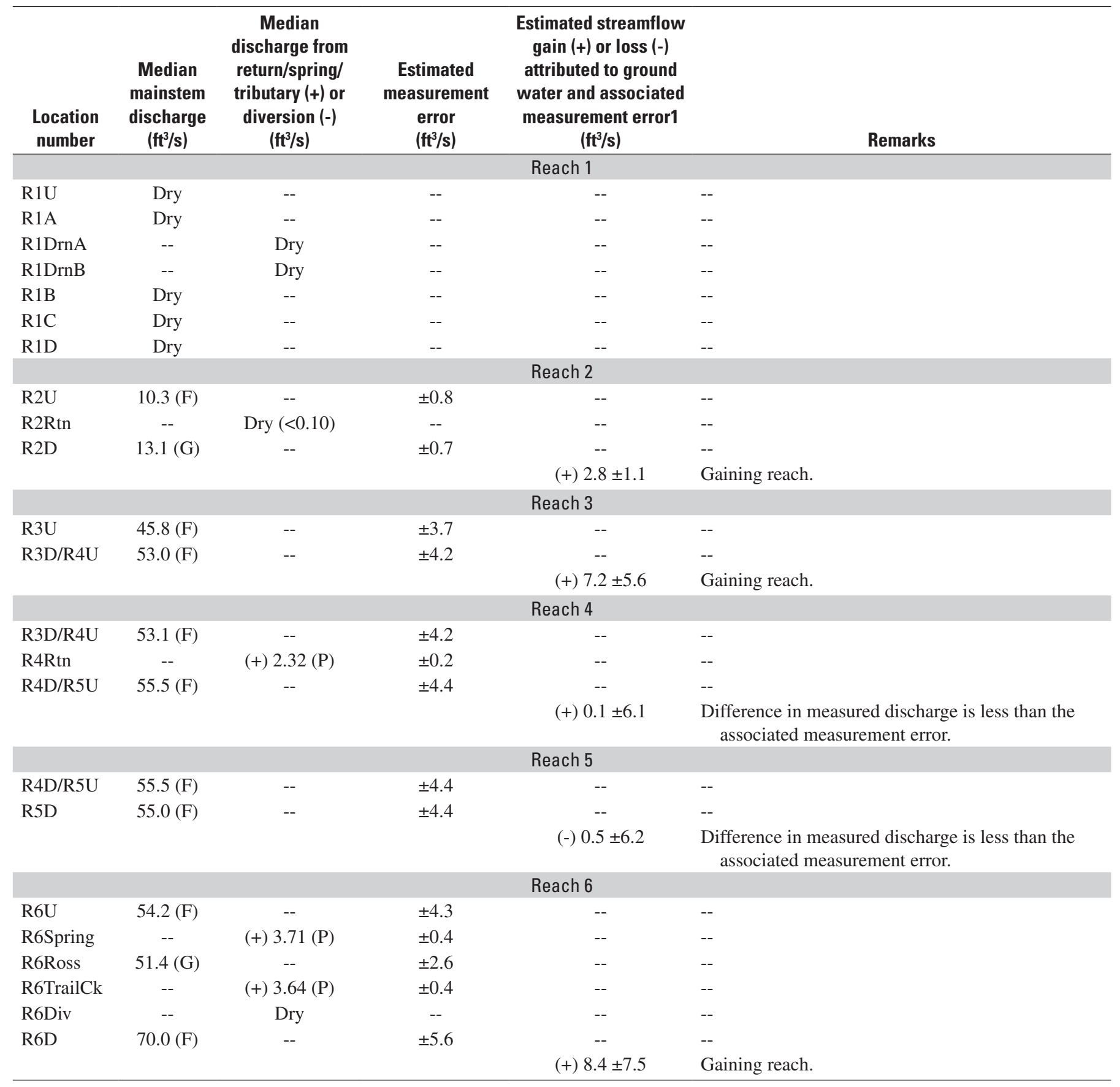

${ }^{1}$ Measurement error for the streamflow gain or loss attributed to ground water was calculated using the following propagation of error formula:

$$
s=\sqrt{( \pm a)^{2}+( \pm b)^{2} \ldots+( \pm n)^{2}}
$$

Where $s$ is the error propagated from all estimated individual errors and $a, b, \ldots, n$ are the estimated errors for the median discharge measurement at each site. 


\section{Summary}

A seepage investigation was conducted during 2004 on Fish Creek, a tributary to the Snake River in Teton County in western Wyoming, by the U.S. Geological Survey in cooperation with the Teton Conservation District. A total of 20 sites including mainstem, tributary, and diversion sites, were selected in six different reaches along Fish Creek. The most upstream site was located approximately where Fish Creek leaves the mountains and enters the Snake River valley. The most downstream site was located approximately 1 mile south of Wilson.

Discharge was measured at all 20 sites on Fish Creek during August 17-19, 2004, which was representative of highflow conditions. The 14 mainstem sites had median discharge values ranging from 0.93 to $384 \mathrm{ft}^{3} / \mathrm{s}$. Median discharge values ranged from 0.35 to $12.2 \mathrm{ft}^{3} / \mathrm{s}$ for the five return, spring, and tributary sites (inflows), and discharge was $2.23 \mathrm{ft}^{3} / \mathrm{s}$ for the single diversion site (outflow). Estimated gains/losses from ground water were calculated for each reach using the median discharge values for each site. Reach 1 had a calculated gain from ground water $\left(23.8 \pm 3.3 \mathrm{ft}^{3} / \mathrm{s}\right)$ that was greater than the estimated measurement errors. Calculated ground-water gains/losses in Reaches 2-6 were smaller than the estimated measurement errors.

All of the sites that were measured during August were revisited during November 3-4, 2004, to make base-flow measurements; 12 sites had flowing water and were remeasured. All of the Reach 1 sites near Teton Village were dry. Median discharge values ranged from 10.3 to $70.0 \mathrm{ft}^{3} / \mathrm{s}$ for the mainstem sites, and from 2.32 to $3.71 \mathrm{ft}^{3} / \mathrm{s}$ on the return, spring, and tributary sites (inflows). Reaches 2, 3, and 6 had calculated gains from ground water $\left(2.8 \pm 1.1 \mathrm{ft}^{3} / \mathrm{s}\right.$, $7.2 \pm 5.6 \mathrm{ft}^{3} / \mathrm{s}$, and $8.4 \pm 7.5 \mathrm{ft}^{3} / \mathrm{s}$, respectively) that were greater than the estimated measurement errors. Calculated gains/losses attributed to ground water in Reaches 4 and 5 were smaller than the estimated measurement errors.

\section{References}

Nelson Engineering, 1992, Teton County westbank groundwater study: Jackson, Wyoming, Nelson Engineering Report, $61 \mathrm{p}$.

Nolan, B.T., and Miller, K.A., 1995, Water resources of Teton County, Wyoming, exclusive of Yellowstone National Park: U.S. Geological Survey Water-Resources Investigations Report 95-4204, 76 p.

Nolan, K.M., and Shields, R.R., 2000, Measurement of stream discharge by wading: U.S. Geological Survey WaterResources Investigations Report 00-4036, on CD-ROM.

Rantz, S.E., and others, 1982, Measurement and computation of streamflow: U.S. Geological Survey Water-Supply Paper 2175, 2 v., 631 p.

Sauer, V.B., and Meyer, R.W., 1992, Determination of error in individual discharge measurements: U.S. Geological Survey Open-File Report 92-144, 21 p.

Swanson, R.B., Woodruff, R.E., Laidlaw, G.A., Watson, K.R., and Clark, M.L., 2002, Water-resources data, Wyoming, water year 2001, Volume 1. Surface Water: U.S. Geological Survey Water-Data Report WY-01-1, 518 p.

Swanson, R.B., Miller, K.A., Woodruff, R.E., Laidlaw, G.A., Watson, K.R., and Clark, M.L., 2003, Water-resources data, Wyoming, water year 2002, Volume 1. Surface Water: U.S. Geological Survey Water-Data Report WY-02-1, 526 p. 
For more information concerning the research in this report, contact:

Director

U.S. Geological Survey

Wyoming Water Science Center

2617 E. Lincolnway, Suite B

Cheyenne, WY 82001-5662

(307) 778-2931

Teton Conservation District

P.O. Box 1070

Jackson, WY 83001

(307) $733-2110$ 
